\title{
FOREIGN AID, NGOS AND THE SOCIAL CONTRACT: WANTING TO HELP, IGNORING LONG-TERM EFFECTS
}

\author{
Devon Knudsen Ochieng
}

\begin{abstract}
This paper aims to review and add to the academic literature criticizing how foreign aid acts as an obstacle to African states in the development of a social contract between state and citizens. In the model contract, the government provides social services in exchange for tax revenue, the right to call upon citizens for national defense, and general adherence to basic rules. However, foreign aid enables the evolution of an entirely different social contract in contemporary African states which involves new actors and exchanges. This paper examines how this new social contract impacts taxes, military service and governance and hopes to prove that the aid-supported social contract has negative longterm effects on African states.
\end{abstract}

\section{Introduction}

The negative effects and ulterior motives of foreign aid and the organizations through which it is delivered have increasingly come under scrutiny. As a result, many donors and NGOs have established mechanisms to address these criticisms, such as building 'partnerships' with stakeholders, placing limitations on donor influence, or adding conditionalities. Despite these attempts to improve the effects of aid, fundamental problems still remain which seem unlikely to be addressed by current efforts. Although these problems have a wide array of causes, many occur because of a systematic undermining of social contract development between states and the people they purportedly represent. 
This is particularly true for African states. If we compare the social contracts between current African states and their citizens to the model social contract as it evolved in Western political theory, elements of African social contracts appear to have been rearranged. This paper will examine why the conventional form of social contract does not appear to be gaining strength in Africa. I will pay special attention to the obstacles facing social contract development as well as the new structure of exchanges currently seen in the African context. This paper hope to prove that the supplanting of taxes by aid, misdirecting of accountability and legitimacy away from the government, and the subsequent disengagement of government have negative effects on governance despite the aid regime's claims to the contrary.

\section{Social Contract}

Western political theorists reaching back to Aristotle have predominantly portrayed the interdependence and exchange between governments and their constituents through the cyclical model ${ }^{1}$ of social contract (Barker ix) ${ }^{2}$. Although variations of the model can be identified, its basic concepts are widely used and have been applied to the study of

\footnotetext{
$1 \quad$ Although mainstream literature does not describe the social contract as a virtuous circle, it is necessary to stress that the social contract comes into existence through a process in which very little is exchanged at first: perhaps the government offers to protect a marketplace from bandits in exchange for a tax on vendor revenue. When both parties agree this exchange is beneficial, they negotiate to broaden the exchange and can grow as large as exists in Sweden for example, with high taxes, high level of social services provided, and mandatory military/civil service for men.

${ }_{2}$ There are two kinds of social contract in Western political theory. One deals with the contract of association in which the individual sacrifices some of his liberty to join society. For an interesting commentary on how this kind of social contract exists in Africa, see Michael Rogin's "Rousseau in Africa.” The other, and the one which this paper is concerned with, is the contract between this society and government, which assumes the first kind of contract already exists (Barker xii).
} 
various forms of government ${ }^{3}$ (Hobbes 111). These basic concepts include three aims of government, whether democratic or otherwise: minimizing the resources required to enforce order, maximizing tax revenue, and ensuring the state's defense by being able to conscript its population for military service. However, another tenet of the social contract says that if the government attempts to obtain these three aims through coercion alone, popular resistance will eventually reach a level of desperation which poses a threat or at least unsustainable costs to the government (Whimster 119). Therefore, to better ensure stability and general acceptance of its rule, the government will provide protection and services to citizens. When citizens feel they benefit from the government in proportion to what the government demands from them (taxes, military service, and general compliance with the law), the government gains legitimacy and strength. Consequently, the strength of a government is partially derived from the skillful management of the social contract. A working social contract can extend the government's reach and longevity. This contract comes into existence through a slow evolutionary process in which there is very little exchanged at first. Over time, the contract expands and strengthens as the government continually tries to get as much from the people without too much rebellion but accepts that citizens will also make demands for improved benefits and reduced hardship (Mamdani 14).

A second critical driving force behind the evolution of the social contract is the threat to the government of being replaced by a stronger or more popular government. In many

3 The rationale being that even in authoritarian regimes, dictators feel pressure to provide some kind of benefits to decrease the likelihood of a coup (Adam 235). 
states, this threat no longer takes the shape of conquering empires or kingdoms, but instead is still felt through rival political parties. However, the effect of the threat remains the same. Governments which find better ways of strengthening the contract cycle and thus increase their financial and military resources, as well as governments which enjoy more public support, are, in theory, at an advantage and may be able to make a bid for power and replace governments having weaker social contracts. States therefore have a strong incentive to initiate and maintain social contract development.

The preceding paragraphs explain how the model social contract works and evolves, but have contemporary states actually followed this theory in the Western birthplaces of social contract theory or elsewhere? If this model has been helpful in state development in some cases, is it a universal path, or is it the result of specific historical circumstances? European and American history fits these theories in some respects. Intra-European wars have played a major part in developing the contract ${ }^{4}$ (Herbst 256). Church institutions, feudalism and "medieval political theory and Roman law," also helped shape the state in the West (Warner 67-9; Barker ix). As some European states developed a social contract, they influenced their neighbors to do the same (Warner 66). The concept of state responsibility for allocating public resources and acting collectively on behalf of their citizens "as the mediator of competing claims" based on general "agreement on the "rules of the game’” spread to rivals and allies alike (Warner 66-8; Jackson 3).

\footnotetext{
$4 \quad$ For explanation, see Military section.
} 
There are certainly limitations to the social contract as it exists in the West. Certain groups of citizens have been more successful than others in leveraging their claims against the government (Mamdani 28). High percentages of citizens of Western countries do not believe they can demand policy changes from their governments (Hertz 12; 20-1), and do not often withhold their taxes, empty the national army with mass desertion, or shake the capital with sustained protests. Noorena Hertz argues that the state answers more to corporations, and citizens find they get faster results by guiding corporations through their consumer choices than through votes or protests against the government (Hertz 142). Social theorist Jürgen Habermas adds that "the rise and domination of the technical [in modern Western states], with its...specialists and its bureaucrats, its dreams of order, predictability and control" creates "a domain [which is] autonomous from and impervious to the critical gaze of the public," giving the state advantages over society in contemporary contract negotiation (Barry 12).

However, despite these problems, Western countries benefit from having undergone a long process of social contract formation and continue to benefit from both citizens and government behaving as if they believed in such a still contract exists (Barker vii). Negotiation between these two sides continues in moderated form. The difficult legacy of battles between the state attempting to consolidate power and the citizens fighting to gain civil liberties and social services currently allows both sides to pursue these same goals through less dramatic means than were previously necessary. 
Although it is important to understand how the social contract has fared in the West, the social contract has followed a very different course in African states, and comparison of social contracts in contemporary African and Western states is problematic. As Kenneth Dipon argues, we cannot assume states follow parallel paths, arriving at similar stages, if at different paces (Warner 67). It would be more constructive to measure African social contracts against the model social contract, in other words, the social contract in its full potential, than against the social contract as it exists in modern-day France, for example. This approach will help reveal how aid derails African states from becoming more responsive to their citizens’ needs.

\section{Social Contract Reexamined}

Historical records indicate that pre-colonial African societies showed evidence of social contracts. Muslim societies collected and redistributed taxes, codified laws, and successfully conquered areas ruled with weaker social contracts (Warner $72,74,77$ ). In addition to Muslim states, many other pre-colonial African kingdoms were starting to mirror the Westphalian state until the onset of colonialism (Warner 69; Morton 215). However, almost half a century after colonialism, the social contract remains either twisted, or in some cases, completely nonexistent ${ }^{5}$.

Today African states do have some level of tax collection, service provision, and military service, but generally speaking, the social contract in its ideal form has not gained much

$5 \quad$ Michela Wrong's description of the Democratic Republic of Congo under Mobutu who told citizens to fend for themselves provides a stark example. 
ground. Although the initial failure to develop the social contract can be largely blamed on the decolonization process, the continued failure to develop it after, in many African countries' cases, half a century of independence is largely attributable to foreign aid.

It would be difficult and wrong to argue that colonization and subsequent decolonization are minor causes of the problems currently facing the African social contract. African states have followed a "radically different state trajectory" than western states (Herbst 257). Therefore, attempts to import Western state structures, "Western blueprints, redolent of the last years of colonialism," stood little chance of success in African societies (Clapham 265-6). Additionally, these imported blueprints were not accurate representations of the colonial powers' own paths to their post-WWII positions of relative power. These structures would cause additional obstacles to state-building newly independent African nations.

Although these states had been denied independence too long, their rushed transition from colony to nation should have heralded calamity. Patchwork bureaucracies were thrown together as African states prepared to enter an international system which was poised to take advantage of having already made and mastered the rules. The colonial powers, wanting to be rid of increasingly difficult appendages, transformed the UN into "a decolonization machine: its primary purpose [being] to proclaim as quickly as possible 
that every country is able to rule itself” (Herbst 257). The result was a region of states with formal sovereignty but questionable hegemony over an artificially defined area (Jackson 4; Chabal and Daloz 25). Although this sovereignty was unearned, it was protected by relatively very powerful external actors (Reno 185; Clapham 263). In this regard, the "African model [of statehood in which] states are easily born but do not die" was “dramatically at odds with traditional western" experience (Herbst 272). In their own experience, Western governments had needed to address their weaknesses or risk losing their authority over the state to domestic or external challengers, whereas new African states were rarely threatened with overt military attack by either neighboring or non-African actors (Jackson 12).

It is clear that organic efforts at state-building including social contract development were interrupted by colonialism and further delayed by the decolonization process. However, to argue that colonialism and decolonization are the only causes behind the lack of viable social contracts in contemporary African states would be to ignore the ongoing challenges facing social contract development.

Currently, some form of social contract does exist in African states. However, the structure of that contract is very different than the model. In the twisted form of social contract seen in contemporary African states, new actors are involved in the exchange. These new actors divert the resources that would normally be exchanged between citizens and state. For example, social services which would normally be funded with tax revenue 
are now often provided with funding from donors. Secondly, taxes which are normally demanded from citizens, whether in the form of income tax, taxes on purchases, or taxes on businesses operating within the country, are often only partially collected. The government instead comes to rely on financial support from donors. A government which does not rely on tax collection can get away with disregarding public welfare (Adam 226). The same can be said for military service. After a wave of attempted and successful coups across the continent, African leaders have often sought the support of foreign military assistance. Foreign forces and other forms of military aid are often supplied in exchange for non-monetary privileges, such as access to strategic minerals or access to influencing the recipient state's economic policies. Military aid is also often not dependent on the leader's success in delivering a better standard of living to citizens. The twisted form of social contract is often found where horrific regimes have been able to withstand challenges for long periods, such as Togo's Gnassingbe Eyedéma, who remained in power for thirty-eight years (Meredith 560). Eyedéma’s long stay in office was not earned through expert procurement of resources from taxation, military power built from dedicated conscripts, or construction of a well-functioning bureaucracy. Instead, these pillars of state-building were systematically ignored and deliberately sabotaged as his position in power was guaranteed by foreign aid and assistance (Meredith 70). The following paragraphs will review these arguments in more detail, attempting to prove that aid is the primary obstacle to each of the basic contract elements.

\section{Taxes}


Taxes have been seen as centrally important in the Western social contract. Cicero calls them the "the sinews of the commonwealth" (Morton 49), Max Weber says they are prerequisite to bureaucracy (Whimster 123) and Thoreau famously refused to pay them when he disagreed with his country’s military aggression (Keen). Ability to collect them requires that the government enjoys a basic level of legitimacy and at least a rudimentary administrative presence throughout its territory. In the model social contract, a portion of tax revenue is redistributed in the form of social services, and it is in the government's interest to govern in a way to help its citizens and economy prosper so that tax revenue increases. Historically, withholding taxes has been the people's “one weapon against the government” in negotiating better terms of the contract (Morton 49; Keen). However, the effort made by African governments to gain revenue through taxation has always been low. Although middle income countries have seen a five per cent rise in taxes between the mid 1970s and late 1990s, the collection of taxes in lower income countries in Africa fell three percent over the same period (Knack 264).

Impediments to taxation such as low population density, lack of accurate census data, and lack of sophisticated tools to prevent tax fraud by corporations offer some excuses (Herbst 251-2). However, as Hertz pointed out earlier, pre-colonial African states managed to collect taxes despite even larger logistical obstacles. Additionally, according to a USAID and World Bank tax consultant, some African states have been offered free bespoke technologies by donors which would enable them to better ensure tax collection 
from large businesses but have refused to use the technology (Carleton). African states now have easier alternative sources of revenue.

All newly independent states face the challenge of simultaneously earning popular legitimacy, consolidating power, and introducing taxation. Most states have no choice but to do their best balancing all three, knowing that if they ignore one, they lose all. However, faced with innumerable challenges, new African governments desperately tried to diffuse discontent by keeping taxes low and getting money from external sources. When discontent reached levels that threatened the new government, taxation was often abandoned and replaced with distribution of aid as patronage (Morton 214). Governments did not feel it necessary to develop the infrastructure required for a working and thorough tax collection system because "from first to last it has been financed externally" (Morton 232; Goldsmith 127). IMF studies show that this is widely representative across African states, and there is a correlation between countries with high aid to GDP ratios and decreased tax effort (Knack 262-4). This is evident in the Sudanese local government's choice to not raise its income taxes to five percent even though this would increase its tax revenue four hundred percent (Morton 222). Politically, it is easier to demand that the central government share more of the foreign aid it receives or attract foreign aid directly to local government coffers. Comparing potential aid income and potential tax revenue makes tax collection seem like a lot of work for little benefit. There is also the added benefit that the donors tend to be easier for the recipient government to control, satisfy or replace than their own citizens (Morton 
216). The combination of more money for less work is provides a welcome shortcut for a struggling new government.

To show their appreciation to donors, the government excuses the aid industry from paying import duties and income taxes on aid personnel salaries on jobs that would be taxed if done by locals. However, this represents a considerable amount of forfeited government income: "at one point in Tanzania, the total government wages and salaries (which are taxed) was $\$ 100$ million, while the salary bill for the technical assistants supplied under aid programs (and not taxed) was \$200 million” (Knack 262). Political leaders would not voluntarily overlook this source of income without receiving something in return.

Tax collection may be more arduous than aid negotiations, but it is precisely because income tax revenue has to be collected in small amounts from many sources, requires so much effort, and is relatively visible that it does not become an enclave market. Aid delivery on the other hand, can be transacted quickly and discreetly in large amounts that often exceeds absorptive capacity (Knack 264; Morton 48). Citizens are likely to feel more ownership over their taxes than an aid transfer, which is not necessarily reported in accessible media. Low taxpayer scrutiny and unabsorbed revenue both increase patronage transfers (Knack 264; Morton 49). ${ }^{6} \quad$ This replaces the social contract with

$6 \quad$ Peter Anassi explains how this has been seen in Kenya. Ministries are aware that if they don't use all of their budgets, which are significantly inflated by donor support, they must return the money to a consolidated fund at the end of the year; this increases the incentive and occurance of corruption (110). 
more complicated but less institutionalized and less dependable exchanges, leaving citizens to rely on creativity or luck in trying to secure state or donor resources.

\section{Military}

The idea that the state must care for or compensate citizens that serve in the military can be seen in cases as diverse as the 1944 GI Bill in the United States to the Zimbabwean government's payment of ex-combatants and claims that land redistribution benefited war veterans (USDoVA; Martin 75). Demanding government services on the basis of military service is not limited to those who directly participate in combat however: in working social contract states, families and communities also claim public services on these grounds. However, aid nullifies the negotiating leverage normally held by those who have served, or whose families and communities have served, in defending their state.

Instead of drafting citizens, many aid-recipient African governments have turned to hiring mercenaries (Herbst 255). The state has more freedom in military actions using mercenaries because high mercenary casualties do not provoke as much public protest as regular military fatalities (Young). In the twisted version of the contract that emerges, foreign mercenaries such as Executive Outcomes are able to rival atrophied state militaries in strength and enjoy more popular support and legitimacy than the national armed forces (Reno 181). 
In states with working social contracts, the high cost of war is funded by redirecting funding away from other social programmes, raising taxes, or going into debt, all of which risk political consequences if the public does not think the war is worth the expense. However, aid can either be used to cover war costs directly or can offset other government expenditures so the government frees up its own budget for war without facing rebellion from entitled taxpayers, veterans, or families of military conscripts (de Waal "Democratizing” 629). Foreign aid to the Biafran movement "prolonged the war by 18 months," and competition over aid resources in southern Somalia exacerbated the conflict (de Waal, “Famine” 77). Rwandan genocidaires were armed by aid hurriedly delivered before the 1994 wave of violence and were enabled to heal, regroup, and rearm thanks to misguided humanitarian aid efforts as the genocide subsided (Prunier 110-3; Melvern 24). In Sudan, "the [aid] money enabled the government to fight a war in the south and to ignore popular pressure in the north for peace. Years of street protests, press criticism and parliamentary resolutions counted for nothing;" it was not until the donors demanded peace efforts that the government responded (de Waal “Democratizing” 627). Some blame the granting of military aid and "unrestricted sovereignty" by the international system for "displacing any need to compromise with other domestic political forces” (Clapham 264).

\section{Governance}

The problems highlighted in the previous two sections are trivial compared to the harmful effects aid has on African states' ability and motivation to govern well. Some academics, 
usually those sponsored by the aid industry, admit that aid is not perfect but argue that its positive contribution outweighs any potential downsides ${ }^{7}$. This section will show that this wishful thinking is disastrously irresponsible.

The logistical obstacles created by aid are fairly straightforward. The high number of aid agencies acting within African countries makes coordination difficult. Overstretched governments must focus their efforts on pleasing donors to receive the external funding they need to stay afloat (de Waal "Democratizing” 627). "In Ghana...senior officials each spent as much as 44 weeks a year facilitating" donor programs, and "were unable to devote [sufficient time] to their ministries and own priorities” (Knack 261). African governments are wary of imposing too strict of regulations on donors who can easily take their money elsewhere. “All over Africa, the government's ability to undertake even minimal regulatory and development planning functions is severely compromised” (Van de Walle “Aid's Crisis” 348). In trying to stay out of politics, donors have sought to deal with the recipient state through technocratic rather than public channels. This not only diverts bureaucratic capacity, but also uses closed-door, non-transparent style decisionmaking, which only reinforces unhelpful norms of informal politics (Van de Walle “African” 228).

The effects of moral hazard problems are more indirect. Aid enables recipient governments to ignore the society they would normally be accountable to and transfers

$7 \quad$ For example, see Nicholas Van der Walle's sponsored work. 
that accountability to the donors (Abruge). "Mick Moore suggests that part of the reason [African governments do not provide more public services] is that foreign assistance gets between the state and the demands of its internal constituencies," thus forming an enclave market (Goldsmith "Foreign” 127). Arthur Goldsmith acknowledges that donors control 10-20 per cent of the recipient country's national income, but still argues that the state does not act according to donor preferences (144). Goldsmith’s logic is hard to entertain when even former leaders of the aid regime admit that "foreign aid in Africa has encouraged poor governance by giving dishonest and incompetent regimes a sense [and source] of security” (Goldsmith 417).

Studies performed by even aid's more ardent advocates prove that "large amounts of aid delivered over long periods may reduce accountability and democratic decision making among recipient states” (Goldsmith 411) and that aid and corruption are positively related (Knack 266). A Kenyan expert on corruption claims that "[i]t is always unlikely that international financial aid will be properly accounted for in a setting riddled with corruption” (Anassi 20). In fact, bureaucrats see aid as an obvious channel for personal enrichment because of the levels of funds involved (Anassi 20). In addition to creating obstacles for corruption reform, Van de Walle argues "that the aid regime has [also] slowed down the process of policy reform” (“African” 189). High levels of aid and state failure go hand in hand, but areas where aid has been unable to reach have developed some of the best African examples of responsive government (de Waal "Democratizing" 630; Herbst 260, 265). 
Goldsmith tries to refute moral hazard arguments by citing the good intensions of donors, but this fails to address a number of points on the opposing side of the debate ("Foreign" 141). Whether or not donors were aware of the secondary effects of their actions at the time, they "helped rulers weather the economic and administrative inefficiencies that patron-client politics generated" (Reno 166). This let politicians "sabotage their own bureaucracies, parceling out state office to local allies to deny them as power bases to potential rivals" without political consequences (Reno 166). With the introduction of aid into the contract cycle, "the heavy use of patronage, the discouragement of restraining institutions, and the emasculation of competing centers of political power" become rational political strategies (Adam 226), whereas without aid these practices would be politically unsustainable.

In some cases, instead of encouraging bad governance, aid excuses governments from governing at all. A representative of an international donor agency complained that "the government is not doing anything...so thank God for the NGOs” (Michael 37), but the NGOs she speaks of and the aid regime is actually highly culpable in the sidelining of the government she criticizes. Goldsmith's doubts that aid has discouraged government effort ("Donors" 412) once again contradict the evidence. Sudan initially showed strong signs of starting to develop a normal social contract, but after a decade of high levels of aid, the government allowed the bureaucracy to fall apart. Aid revenue did not require a 
working bureaucracy, so state institutions were allowed to atrophy and the linkages between the central and local governments disintegrated (Morton 218).

The impact of moral hazard problems increases with time. Even politicians who resist available shortcuts are still discouraged from active policy making because if their policies offend donors, aid could be withheld or delayed, having a negative, immediate impact on their constituents. "Once [the politicians in the recipient country] understand that donors mean to set policy, ministries become passive” (Knack 262), even forfeiting national sovereignty to the extent that expatriates are allowed to assume high positions in African governments (Harrison 671; de Waal “Famine” 53). Even Goldsmith concedes that this derails state-building (“Foreign” 144).

Donor preferences are put in such exalted position in the policy making process that some states preemptively request that donors draft government policies to insure the policies meet conditionalities and are received favorably by donors (Harrison 669). This removes domestic public opinion from decision making processes and should be a red flag to donors that they are not fostering real 'local ownership.' This causes a kind of "mental tyranny" over the African state (de Waal "Democratizing" 624), unhelpfully reopening colonial scars.

\section{Conditionalities and Accountability to Donors Do Not Work}


The usual defense against moral hazard problems is that conditionalities transfer accountability to tax payers to accountability to donors. Advocates of this position often cite three examples of conditionalities bringing about improvements in governance. In these three cases concerning electoral laws in Kenya, staple food prices in Zambia, and coup perpetrators not wanting to hold an election in Niger, aid was removed following the failure to meet conditions. In each case, withholding aid pressured the government to address the specific violation concerned. Aid was then immediately resumed. Unfortunately these examples are not representative: ${ }^{8}$ threats to withhold aid are rarely enforced, and for each success story, a long list of other conditionality violations as well as underlying problems remain unresolved (Goldsmith “Donor” 416).

When donors shape governance, they see the results of their actions from a distance and do not bear the costs of their mistakes. This encourages riskier policies than a constituent of the recipient country would choose (Knack 264). This kind of "generalized, international responsibility...is far less valuable than specific, local political accountability" (de Waal "Famine" 5). The aid industry "cannot establish any such political contract" in which both service provider and recipient recognize equal interdependence because the donor can walk away (de Waal "Democratizing” 630). Accountability to donors is in fact soft accountability, in which the recipient government is aware the rules are flexible, and can get away with having "expenditures bear little

\footnotetext{
8 In fact, Stephen Brown argues that in this case, although donors were able to help bring about multipartyism, they also helped Moi continue winning elections after multipartyism was introduced. For example, donors hid evidence that Moi had stolen elections on two occasions. (725)
} 
relation to revenues" (Knack 264). Reckless donors "act like creditors who, having seen their investment lost by a company without a viable business plan, seek to reinvest in the same company after bankruptcy has been reached but without demanding a restructuring” (Herbst 258).

Some argue that constituencies in donor countries hold their governments responsible for the success of their aid policy, but this is overly naïve. It is unlikely that donor country voters will either know or care about the needs of recipient societies enough to make those needs a political priority. NGOs are no more reliable because most are impervious to criticism, especially criticism from those who rely on their services (Michael 18).

"Some critics...seek to make a sharp distinction between the last two decades in which the donor community has conditioned its aid...and the earlier period of" Cold War strategic aid (Van de Walle “African” 190). Lumsdaine argues that strategic aid only constitutes a small percentage of total aid and the rest is free of the problems inherent in strategic aid (55) and is based more on partnership, trust, and generosity. Others defend strategic aid, saying it is less paternalistic and leaves decision making in the hands of African politicians, but beneath the rhetoric, both kinds of aid are based very much on the same internal logic (Van de Walle “African” 190).

Advocates of the more recent non-strategic aid often point to conditionalities as a way to prevent the moral hazard problems of earlier eras. However, at their best, conditionalities 
only address "individual policies," and do not have the tools to change policy making processes (Adam 248). Unless donors want to enforce conditionalities indefinitely, the underlying processes also need to change. Conditionalities prioritize one issue to the detriment of the quality of governance in general (Reno 183). Inconsistent enforcement and methods of getting around conditionalities make them more of an inconvenient show to be put on for donors than a useful tool (Morton 232; Harrison 675). In 1990, President "Mitterrand warned African heads of state that French aid would henceforth be conditional on progress in the direction of democracy...Yet France ignored human rights abuses by” both Chadian leader Idriss Déby and Rwandan president Habyarimana (Goldsmith "Donor" 418). Even after the Cold War, when some donors temporarily withheld aid, recipient states have been able to "re-work old ties to gain access to new resources and manipulate apparently harsher demands from outsiders” (Reno 166). Even if conditionalities are capable of bringing occasional short-term benefits, their downsides show they are not a panacea for interference in the social contract.

\section{Conclusion}

Developing a working social contract is a critical part of state-building, but most contemporary African states have developed a twisted form of social contract which is starkly different from the model developed by western political theorists. Although colonization and decolonization delayed social contract development in Africa, currently the main obstacle to healthy social contract development in African states is the introduction of the aid industry into the cycle of exchange. Aid disrupts the normal cycle 
of exchange by providing the government with alternatives to tax collection and military conscription. Aid also replaces the government in the provision of social services. Citizens' expectations of their government change, and citizens lose both ability and motivation to hold their government to account. Donors also fail to hold recipient governments to account and have a negative impact on governance. Citizens of African states need to be aware of the harmful long-term effects brought about by the short-term solutions offered by the aid industry and pressure their governments to transition away from short cuts in state-building. Only the reversal of current aid policies can allow for the development of a working social contract which benefits citizens and strengthens the state. 


\section{References}

Abruge, Charles and Robert Calderisi. Public Lecture. "Why we should halve aid to Africa.” 27 Sept 2006. SOAS, London.

Adam, Christopher and Stephen O’Connell. “Aid, Taxation, and African Development.” Economics and Politics. Vol. 11, No. 3. 1999.

Anassi, Peter. Corruption in Africa: The Kenyan Experience. Trafford. Canada. 2004.

Barker, Sir Ernest. “Introduction.” Oxford University Press. Oxford. 1947. Social Contract: Essays by Locke, Hume, and Rousseau.

Barry, Andrew, Thomas Osborne and Nikolas Rose. Foucault and Political Reason: Liberalism, Neo-liberalism and Rationalities of Government. Routledge. London. 1996.

Brown, Stephen. “Authoritarian Leaders and Multiparty Elections in Africa: How Foreign Donors Help to Keep Kenya's Daniel Arap Moi in Power.” Third World Quarterly. Vol. 22, No. 5.pp. 725-739, 2001.

Carlton, Van. Personal Interview. Nairobi, Kenya. 10 March, 2009.

Chabal, Patrick and Jean-Pascal Daloz. "Africa Works: Disorder and Political Instrument.”

African Issues. Series. eds. Alex de Waal and Stephen Ellis. James Currey. Oxford, 1999.

Clapham, Christopher. "Discerning the New Africa.” International Affairs. Vol. 74, No. 2.pp.263-269. 1998.

De Waal, Alex. “Democratizing the Aid Encounter in Africa.” International Affairs. Vol. 73, No. 4 pp.623-639. 1997.

De Waal, Alex. "Famine Crimes: Politics and the disaster relief industry in Africa." series. African Issues. James Currey and Indiana University Press. London, 1997.

Goldsmith, Arthur A. “Donors, Dictators and Democrats in Africa.” The Journal of Modern Africa Studies. Vol. 39, No.3. pp.411-436. 2001.

Goldsmith, Arthur A. "Foreign Aid and Statehood in Africa.” International Organization. Vol. 55, No. 1 pp.123-148. 2001. 
Harrison, Graham. "Post-Conditionality Politics and Administrative Reform: Reflections on the Cases of Uganda and Tanzania.” Development and Change. Vol. 32 pp.657-679. 2001.

Herbst, Jeffrey. States and Power in Africa: Comparative Lessons in Authority and Control. Princeton University Press. Princeton, New Jersey. 2000.

Hertz, Noorena. The Silent Takeover: Global Capitalism and the Death of Democracy. Arrow Books. London. 2001.

Hobbes, Thomas. Leviathan. The Project Gutenberg. May 2002. Pelican Classics. 10 Sept 2007

<http://www.gutenberg.org/catalogue/world/ readfile?fk_files $=3488 \&$ pageno $=111>$.

Jackson, Robert H. and Carl G. Rosberg. "Sovereignty and Underdevelopment: Juridical Statehood in the African Crisis.” Journal of Modern African Studies. Vol. 24, No. 1. pp 1-31. 1986.

Keen, Judy. “"War on Tax’ waged against costs of war.” USA Today: Nation. 13 Apr 2006. 15 Sept 2007 <http://www.usatoday.com/news/nation/2006-04-13-taxwar_x.htm>.

Knack, Stephen and Deborah A. Bräutigam. "Foreign Aid, Institutions, and Governance in Sub-Saharan Africa.” Economic Development and Cultural Change. University of Chicago Press, 2004.

Lumsdaine, David H. Moral Vision in International Politics: The Foreign Aid Regime, 1949-1989. Princeton University Press. Princeton, USA. 1993.

Martin, Robert. “The Rule of Law in Zimbabwe.” Zimbabwe in Crisis: The International Response and the Space of Silence. Eds. Ranka Primorac and Stephen Chan. Routledge. London. pp 65-79. 2007.

Melvern, Linda R. A People Betrayed: The Role of the West in Rwanda's Genocide. Zed Books, London, 2000.

Meredith, Martin. The State of Africa: A History of Fifty Years of Independence. The Free Press. London. 2005.

Michael, Sarah. "Undermining Development: The Absence of Power Among Local NGOs in Africa.” African Issues. James Currey, Indiana University Press. London, 2004 
Morton, James. The Poverty of Nations: The Aid Dilemma at the Heart of Africa. I.B. Tauris. London, 1994.

Prunier, Gérard. The Rwanda Crisis: History of a Genocide. Hurst and Company. London 1995.

Reno, William. “African Weak States and Commercial Alliances.” African Affairs. Vol. 96, No. 383. pp. 165-185. 1997.

Rousseau, Jean-Jacques. The Social Contract: or Principles of Political Right. Book 1, Sections 8-9 "The Civil State," "Real Property". The Constitutional Society. $<$ http://www.constitution.org/jjr/socon.htm. 2 Sept 2007 1762>.

US Department of Veteran Affairs (USDoVA). “GI Bill History.” 10 Jul 2007. 4 Sept 2007 <http://www.gibill.va.gov/GI_Bill_Info/history.htm>.

Van de Walle, Nicholas. “African Economies and the Politics of Permanent Crisis, 1979 1999.” Series: Political Economy of Institutions and Decisions. Cambridge University Press. Cambridge, 2001.

Van de Walle, Nicholas and Timothy A. Johnston. Improving Aid to Africa: Policy Essay No. 21. Johns Hopkins University Press, Overseas Development Council, Washington D.C. 1996.

Van de Walle, Nicholas. “Aid's Crisis of Legitimacy: Current Proposals and Future Prospects.” African Affairs. Vol. 98, No. 392. pp.337-352. 1999.

Warner, Carolyn M. “The rise of the state system in Africa.” Review of International Studies Vol. 27, pp 65-89. 2001

Whimster, Sam. The Essential Weber: A Reader. Routledge. London. 2004.

Wrong, Michela. In the Footsteps of Mr. Kurtz: Living on the Brink of Disaster in Mobutu's Congo. Harper Collins Publishers. New York, NY. 2001.

Young, Tom. “'New’ Conflict and 'Humanitarian’ Intervention.” Academic Lecture. International Politics of Africa. 23 Feb 2007. SOAS. London. 